First Peoples Child \& Family Review

A Journal on Innovation and Best Practices in Aboriginal Child Welfare Administration, Research, Policy \& Practice

\title{
A way of life: Indigenous perspectives on anti oppressive living
}

\section{Robina Thomas and Jacquie Green}

Volume 3, Number 1, 2007

URI: https://id.erudit.org/iderudit/1069529ar

DOI: https://doi.org/10.7202/1069529ar

See table of contents

Publisher(s)

First Nations Child and Family Caring Society of Canada

ISSN

1708-489X (print)

2293-6610 (digital)

Explore this journal

Cite this article

Thomas, R. \& Green, J. (2007). A way of life: Indigenous perspectives on anti oppressive living. First Peoples Child \& Family Review, 3(1), 91-104.

https://doi.org/10.7202/1069529ar

\section{Article abstract}

The focus of this article is on the key elements of anti oppressive practices as examined by two Indigenous women who practice and teach anti-oppressive ways. Anti oppressive living is characterized as a "Way of Life" that values the sacred and traditional teachings of various Indigenous cultures. The medicine wheel is discussed and highlighted as an effective teaching tool to examine antioppressive ways of living, practicing and perspectives.
This document is protected by copyright law. Use of the services of Erudit (including reproduction) is subject to its terms and conditions, which can be viewed online.

https://apropos.erudit.org/en/users/policy-on-use/ 
First Peoples Child \& Family Review

A Journal on Innovation and Best Practices in Aboriginal Child Welfare

Administration, Research, Policy \& Practice

\title{
Volume 3, Number 1, 2007, pp. 91-104
}

\section{A way of life: Indigenous perspectives on anti oppressive living}

\author{
Robina Thomas and Jacquie Green
}

For the past five or six years, we have been asking ourselves: "what is anti-oppressive practice?" "And, how would we know that someone was, in fact, living and practicing antioppressively?" More specifically, as Indigenous women, we question, what anti-oppressive practice would look like through an Indigenous lens. We have begun to identify some of the key elements of antioppressive practice (AOP), which include but are not limited to the following:

- AOP is necessarily complicated and uncomfortable. AOP requires grappling with issues of justice and oppression that can be challenging and frustrating as we explore issues of oppression through our own experiences, our own lives, and locations in the world. These explorations, complexities and tensions are necessary because as helpers, we engage with people's personal and intimate lives and well-being; knowing what our values and beliefs are, where they come from, and how they affect specific relations are important in developing a commitment to overcoming injustice in our practice with clients;

- AOP, at its core, must include an analysis of power and strive to work across differences;

- AOP forces us to critically examine how we know what we know and to explore our assumptions not only about helping, but about other human beings. AOP invites us to connect our subjective lived experiences to our knowledges - that is, what we know may be connected to who we are. AOP offers an opportunity to explore the interconnections between 'who we are,' and biases, beliefs, and attitudes towards other (marginalized) groups of people. 
Mindful of, and using these key elements, we will discuss our collective perspectives of anti-oppressive practice as Indigenous women. Many people may ask for a definition of anti-oppressive practice; in this paper, we will demonstrate and show that for us, as Indigenous women, AOP means "A Way of Life" - a Way of Life that values the sacred and traditional teachings of various Indigenous cultures. Specifically, we will utilize teaching philosophies of the Medicine Wheel to frame and discuss our AOP perspectives.

The Medicine Wheel is an ancient teaching tool. It has no beginning and no end and teaches us that all things are interrelated. The circularity of the wheel we are utilizing is comprised of quadrants that represent all living things (see Diagram 1). There are many teachings, principles and philosophies of the Medicine Wheel. Our teachings come from our Anishnaabe friend and mentor, Gale Cyr. She is from the East of Turtle Island - Quebec, Canada.

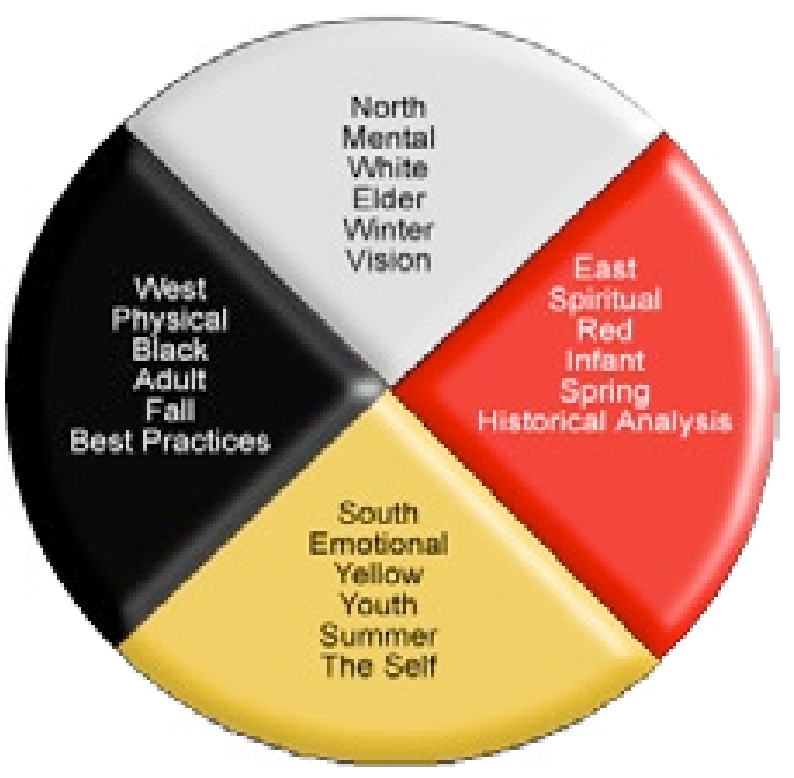

Diagram 1: Medicine Wheel
As stated above, it is important to remember that when we use the Wheel, each quadrant is interrelated. For example, the Eastern direction represents our spiritual being, which is in turn, also connected to the physical being of the Western direction. No quadrant is worth or valued as being greater than the other quadrants; all aspects of our being and place are of equal importance and are positioned in balance and harmony with one another. Moreover, once you have journeyed around the Wheel, you have the opportunity to learn from your experiences and journey around the Wheel again, this time learning from your mistakes. What the Wheel teaches us to be conscious of is that if we remember what the challenges were in our previous journey, then our next journey can be different and more effective. Starting at the East and working clockwise around the Wheel, we have the four aspects of all human beings - the spiritual, emotional, physical, and mental (Bopp et al., 1989, p.12; Saulis, 2003, p.294). The Wheel also has four colours to represent all the races of Mother Earth: red, yellow, black and white. It also provides us the four stages of the lifecycle - infant, youth, adult and elder, as well as the four seasons - spring, summer, fall and winter (Hart, 2002, p.40). As we will show, each of these representations have particular meanings for both life and anti-oppressive practice.

Our teachings about using Medicine Wheel philosophies emphasizes that we are to always to begin in the East because this is the direction of spirituality, the colour red, the life stage of the infant and spring time. This is the direction of new beginnings, of daybreak, and the sunrise. In this paper, we will focus on the Eastern direction to examine the history of Indigenous peoples in Canada and the impact of colonization - the history and beginning 
of Indigenous relationships with settlers and their policies. This history of colonization is a vital to understanding the contemporary lives and subjective experiences of Indigenous peoples, and the ongoing relationships between Indigenous people and the Canadian settler state.

The South is the direction of our emotional being, the colour yellow, and the life stage of youth. This is the direction of summer, a time for lots of activity. For youth, this is a time in their life where they are learning much. The Southern direction is also the place where we recognize and honour teachings of our Elders and spiritual leaders. In this direction, our paper will look at the Self and how we know what we know - we will focus on, and examine how heightened and complex our identities have become because of our interaction with nonIndigenous people.

In the West, we have the direction of our physical being, the colour black, the life stage of the adult and the fall or autumn season. This is the direction we look towards when we do our work and our practice. For example, the Western direction is where social workers share their knowledge and work within our communities to help strengthen our children and families. In this direction, our paper will focus on the following issues: the particular skills that AOP requires; the historical analysis of relations as a necessary skill for anti-oppressive practice; and lastly, we identify critical self examination as yet another necessary skill, and demonstrate why this skill is so vital for anti-oppressive practice.

The North is the direction of our mental being, the colour white, the life stage of an elder and wintertime. When we reach the North, we are reminded to revisit our work. This is the time to focus on what changes we need to make to our lives; a time to re-think and re-evaluate our actions and behaviours. For social work practice in Indigenous communities, this is the direction of vision. This is the time to dream of anti-oppressive living. The northern direction is the time where our language, culture and tradition are revived and become a part of our day-to-day lives.

The text that follows helps us to journal through all the aspects of the medicine wheel which assist us in practicing anti-oppressively.

\section{Beginning In the East We Will Start Our Journey by Our Current/Historical Analysis}

Given that "colonialism has racism as it ideological rationale," (Maracle, 1996, p. 89) an analysis of the impact of colonization on the lives of Indigenous people in Canada is absolutely necessary if social workers are to practice in an anti-oppressive way. The Merriam-Webster's Collegiate Dictionary: Tenth Edition describes colonialism as:

1: the quality or state of being colonial;

2: something characteristic of a colony;

3 a: control by one power over a dependent and or people b: a policy advocating or based on such control ...

However, as those of us who have lived the experience of colonialism (and continue to live in it) know, colonialism is a much stronger force than these mere words reflect: in fact, it is life altering for the Indigenous people of Canada (and colonized peoples world-wide). In a recent article, Taiaiake Alfred (2004) argues that colonialism "is the fundamental denial of our freedom to be Indigenous in a meaningful way, and the unjust occupation of the physical, social, and political spaces we need in order to survive 
as Indigenous peoples" (p.89). This articulation encapsulates the depth and breadth of the impact and effects of colonialism.

Colonization is about taking control of our lives, lands, resources, and people -- at any expense, and at the cost of Indigenous people's lives and livelihood - to make those lands productive in terms of economic rewards (Tuhiwai Smith, 2002, pp.20-22). In other words, capitalism and colonialism have an intimate and necessary relationship. Ania Loomba (1998) describes this interdependent relationship in the following way:

Thus we could say that colonialism was the midwife that assisted at the birth of European capitalism, or that without colonial expansion the transition to capitalism could not have taken place in Europe (p.4).

In Canada, the federal government went to great lengths to ensure that capitalism not only materialized, but flourished. The government ensured the growth of capitalism and solidified their colonial stronghold through the development of extensive legislation, indicating the extent to which Canada was willing to go to guarantee that Indigenous people did not get in the way of progress (capitalism) (Tully, 2000, p.38). In order to subjugate and oppress Indigenous people, the Canadian settler state required the creation and maintenance of violence (Hodge, 1990, p.93); this violence took on a complex and intricate web aimed at destroying the mind, body, spirit and humanity of our peoples. Colonial violence took on different manifestations, including, but not limited to: the Indian $\mathrm{Act}^{1}$ in its assorted manifestations; biological and germ warfare; theft of cultures, knowledges, traditions, languages and identity; residential school policy; child welfare policies; and various treaty processes.

While capitalist expansion was critical to colonial enterprise, colonialists were equally interested in the moral and cultural lives of Indigenous people (Tuhiwai Smith, pp. 2526). Through the Indian Act and the residential school policy, the government launched an official policy of dispossession and cultural genocide in 1920. Our children were forcefully removed from their homes, their families, their communities to be Christianized and civilized (Aboriginal Healing Foundation [AHF], 2003, p.27). In these isolated and foreign places, Indigenous children were forced to speak a language they did not know, pray to God they knew nothing of, and be educated in a way that was both alien and purposeless for them. The effect of these policies was to degrade the Indigenous people of Canada and to position them in the lowest strata of society (AHF, 2005, p.43-44). The education received in those institutions was minimal at best [AHF, 2003, p.29); the children were, in fact, being trained to become the working class (AHF, 2005, p.34) - the labourers, housekeepers, and maids for the emerging white nation. This was done in a very deliberated, thoughtful and planned way.

Modern colonialism did more than extract tribute, goods and wealth from the countries that it conquered - it restructured the economies of the latter, drawing them into a complex relationship with their own, so that there was a flow of human and natural resources between colonized and colonial countries (Loomba, 1998, p.3).

In 1887 the Indian Act was amended to ban our potlatch and sun dances. The potlatch and other traditional ceremonies were and still are our traditional governance systems. For example, in the Thi'lelum (Big house) we pass on names, 
Chieftainships, songs, dances, masks; performed marriages; supported our families (funerals); and redistributed our wealth through give aways. For Indigenous people, the ceremonies performed in these sacred places constituted both the administration and governance of community members - in effect, these ceremonies served similar functions to Western structures like the Department of Vital Statistics and Parliament. By destroying our community governance, the Canadian state threatened and attempted to eradicate our communal identity and the status of our Nations'.

In many Indigenous languages, there is no word that translates to 'anti-oppressive practice.' However, there are various phrases in our mother tongue that identifies "A Way of Life". For example, phrases and/or terms such as Snuw'uy'ul' roughly translates into our 'teachings' - our ways of knowing and being, our governing structures, our culture our tradition, our language, our sacred bathing holes, hunting, fishing and gathering rights, our family, our community, our relationship with Mother Earth and Father sky. Through the banning of the potlatch (and other traditional ceremonies) the government specifically and purposefully attacked and attempted to rupture Our Way of Life ${ }^{3}$ (Lawrence, 2002, pp.23-24). Indigenous scholar Lee Maracle (1996) captures the spectrum of these ruptures:

The aims of the colonizer are to break up communities and families, and to destroy the sense of nationhood and the spirit of cooperation among the colonized. A sense of powerlessness is the legacy handed down to the colonized people. Loss of power - the negation of choice, as well as legal and cultural victimization - is the hoped-for result (p.93).

Through their power to define 'Indians' as inferior and the development of racist policy, the Canadian state directly attacked Our Way of Life, Our Way of Being (Simpson, 2000, p.118). Many of our people, both the young ones and the older ones, remember the pain and devastation of the days when the potlatch was banned and residential schools were still open.

The state also used education to push forward Eurocentric beliefs. Maracle (1996) believes, "the appropriation of knowledge, its distortion and, in some cases, its destruction, was vital to the colonial process" (p.89). Education had an assimilationist agenda (Castellano et.al. 2000, p.25), requiring our people to assume the cultural, social and political belief systems of the colonizer as part of the "civilizing mission' that was directed towards Indigenous peoples (AHF, 2005, p.42). The education process had, as its underlying agenda, to ensure that our people would believe their knowledges and traditions - their Way of Life - to be inferior; this was due in part to the colonialists' own thinking that Indigenous epistemologies were inferior (Tuhiwai Smith, 2002, p.11). Having our knowledges targeted for destruction, and having to assimilate into Western knowledge systems, has had significant psychological impact on our people. As a result of Eurocentric educational indoctrination, Indigenous people began to forego their ways of life in order to be more like the 'superior' others. bell hooks (1995), when discussing colonization of the mind in Black communities, claims that "...through being taught/socialized Eurocentric biases black [people] began to long for the "rewards" that whites had access to (luxury and comfort). To gain access to these rewards, blacks began assimilating white values." However, assimilating white values may be easier than having the dominant society accept our Way of Life. The experience of 
racism has meant that Indigenous people have internalized racism, domination and colonization.

Given the colonial history of Canada, anti-oppressive practice with Indigenous people requires an intimate knowledge and understanding of the history of Indigenous people in Canada, including the ways in which the colonization of lands, resources, psyches, and hearts of Indigenous peoples was an integral part of colonizing processes The Indian Tribes of Manitoba (1971) remind us of the significance of linking history to the present and to the future by stating "To deny the past and to refuse to recognize its implications is to distort the present; to distort the present is to take risks with the future that are blatantly irresponsible" (p. ii). As social workers, we must understand the impact these policies have had, and continue to have on the day-to-day lives of our children and families that we work with. It is critical for social workers to question themselves and their knowledge of Indigenous peoples by asking themselves: what have the experiences of the Indigenous children and families been? Did they, their parents and/or grandparents attend residential schools? Have they been involved in the child welfare system and how might they feel about social workers? What is their history with social work? What are their fears? We must always take these questions into account when we work with Indigenous children and families. We must always situate the present within the context of the past, and continuously engaging how the families we support come to know what they know. Maracle (1996) believes that "change must be the basis for education" (p.92). Change can only begin by knowing and engaging the effects of where we have come from and knowing and engaging the effects of where the children and families we support have come from.

\section{In the Southern Direction We Journey To Reflect On Self}

As time went on, we realized that anti-oppressive practice is not enough. We cannot decide when or when not to practice - it must be about living - anti-oppressive living. Anti-oppressive social work, in essence, is A Way of Life. In her book killing rage: ENDING RACISM, bell hooks (1995) discusses Martin Luther King's image of a "beloved community where race would be transcended, forgotten, where no one would see skin color" (p.263). hooks eloquently reminds us that King's dream of a beloved community can only be realized if we resist the need to transcend history and to forget the everyday processes of racialization. A beloved community can only be made possible when we forge individual and collective bonds based on "loving ties of care" (hooks, 1995, p.264). And so, not only is it critical for social workers to practice and live antiracism, it must go hand in hand with creating $\mathrm{A}$ Way of Life - a "beloved community" cultivated from care that centers differences that is so crucial to the theory and practice of anti-oppressive living.

Others also offer the gift of living in a more just way - of fostering a more just society. In his latest book Wasase, Taiaiake Alfred (2005) encourages us to become warriors again - those who carry the burden to peace (p.51). He believes that behaving 'indigenously' is a personal attribute that is observable. He also states that we need to "recreate a life worth living and principles worth dying for" (p.25). For us, this is also about A Way of Life - how we are and want to be in the world.

We believe that the same is true for antioppression - we must live it. Our beloved community would foster anti-racist/anti- 
oppressive living. But the question becomes: what do we need to do to get there?; and how do we get to living anti-oppression? hooks (1995) says that, "To live in anti-racist society we must collectively renew our commitment to a democratic vision of racial justice and equality" (p.271). And, Dominelli (1988) believes that:

...to become fully human and live in egalitarian harmony with black people, white people have to become anti-racist. Anti-racism is a state of mind, feeling, political commitment and action (p.16).

hooks and Dominellis' statements on antiracism holds true for anti-oppressive living - we must be committed to justice and equality in all aspects of our lives, and be willing to do something about it. It is not enough to merely recognize that inequalities and injustices exist; that is, anti-oppressive living is neither passive nor something we do in our "job." Rather, it is an active stance and way of being in the world around us. As social workers we must continue to strive for social justice not only to benefit ourselves, but to benefit all our children.

In order to strive for social justice, we must begin this process by asking ourselves how we know what we know. Rarely do we have the opportunity to turn inwardly and look into our life and critique how we have been socialized and what we have internalized from our socialization. We believe that the best helpers are those that know their self best. Dominelli (1988) believes that by "getting rid of the injustice perpetrated by racism we will begin reclaiming our own humanity and establishing egalitarian relationships between black and white people" (14). If anti-oppression is about living, then reclaiming and politicizing our humanity must be a starting point. Seletze (Delmar Johnnie, Cowichan, personal interview) believes that healing is life long and that every day we can strive to be a better person than we were the day before, and a better person the next day than we were today. Yes, we can all heal and become more fully human. Bopp et al (1984) in The Sacred Tree: Reflections on Native American Spirituality include a Code of Ethics. The first Ethic states:

Each morning upon rising, and each evening before sleeping, give thanks for the life within you and for all life, for the good things the Creator has given you and others and for the opportunity to grow a little more each day. Consider your thoughts and actions of the past day and seek for the courage and strength to be a better person. Seek for the things that will benefit everyone (p.75).

We believe that if helpers thought critically everyday about their ways of living, then we would be a step closer towards committing to anti-oppressive living.

Indeed, being committed to living antioppression requires that we not only examine our values and beliefs but live them out as well. As helpers, we must believe that we are good helpers or we would not be in social work. But we need to question our intentions and motivations, and ask ourselves: Are we good helpers? Do we truly value all human beings? When we see the "stereotypical" Indigenous person on the streets, do we value them? Do we care about the poorest people? When we work with people from the gay, lesbian, bi-sexual, transgendered and queer community do we value them? And what about people who live with disabilities? These are tough questions, but they must be examined. Exploring our values and beliefs is very difficult, but a commitment 
to anti-oppressive living requires that we do just this. The eighth code of ethic from The Sacred Tree states:

All the races and tribes in the world are like the different coloured flowers of one meadow. All are beautiful. As Children of the Creator they must all be respected (p.80).

A commitment to continuously examine our values and beliefs can be instrumental in living anti-oppression, which in turn, informs how we will practice social work.

\section{Now We Journey To Look At How Our History and Reflective Self Inform "Best Practices" - In the Western Direction}

In our examination of praxis we have come to know and understand that praxis must include an analysis of Indigenous histories. We also understand that praxis must include a continuous reflection of self. A research study on best practices in First Nations communities identified the importance of knowing self in practice:

One worker talked about always having to remember where she was from and why she was doing this work. It was the personal commitment to her community that kept her strong and wanting to do social work, but also remembering that she was, at the same time, a social worker and a First Nations person. She always had to remember the historical issues that have impacted our people while at the same time remember our traditional ways (Green and Thomas, 2005, p.10).

One critical skill in social work practice requires an examination and understanding of our assumptions. For example, there are assumptions around Indigenous people living on or off the reserve system. Non-Indigenous peoples at times assume because one lives on reserve, they are necessarily cultural, culturally aware, and/or traditional. As we explore our histories, we see how for one, reserve systems are colonial regimes (Simpson, 2000, p.126). As well, we understand that while reserves were created to isolate our people from dominant society, our children were simultaneously removed from our 'reserves' to learn how to assimilate into dominant society. Having said this, many people who live within and among the reserve system are truly connected to one another. Moreover, those who live in urban settings gravitate towards, and are connected with one another. The point here is, that no matter where Indigenous peoples live, they/ we do make connections with each other and nurture relationships and traditional teachings interchangeably. For this reason, much of our work is based in the communities we live in - our work in closely linked to the issues of our community, and we work hard to pay attention to what our community members tell us.

Fostering these relationships is important for our learning, for our teaching, for our practice, and for our communities.

Another set of skills required of social workers is a fundamental understanding of colonialism and colonial relations. In research engaged by Green and Thomas (2005), social workers whom they interviewed believed all social workers must have sound knowledge of the history of Aboriginal peoples. As well, these workers suggested social workers pay particular attention to the history of the geographical area where one is working (p.8). By attending to, and understanding our histories and lives, social workers will come to understand that, in contrast to colonial policies, traditional teachings are rooted in understanding our 
connections to Mother Earth and Father Sky. It is through our ceremonies that we understand our identities and our cultures - no matter where we live - and these ceremonies are important to our social, political and economic knowledges. Cajete (2000) goes on to say it is the intimate relationship that people establish with place and with the environment and with all things that make them or give them life (p.183). Thus, skills of reflection and locating our histories are integral to unraveling assumptions we make of Indigenous peoples and the lives we live.

Common assumptions made about Indigenous peoples are based in racist stereotypes and racist attitudes. Sinclair (2004) states that even in the new millennium, the standard for social work education and practice is literature and education based on the worldview, life ways, and reality of the dominant, predominantly white, and mainstream society (p.53). What helpers must recognize is that, due to residential school trauma and other racist policies, many Indigenous peoples have had to deal with multi-generational trauma. For many, substance misuse is an antidote to numb historical pain. It is critical that helpers come to understand history and see how we can work together to heal from our past. Many people fail to see the strengths and resiliency of Indigenous peoples. As an example, if we as practitioners, when working with families focus on, and look for strength of a person (rather than always exerting energy on 'fixing' a person), families may then have an opportunity to recognize and work through their own strengths. We believe that it is the beliefs, stereotypes, and attitudes of social workers that must shift, rather than a constant centering of 'clients' to fix and shift their behaviours and attitudes. Working with families from a strength-based model requires a commitment to valuing and honouring relationships. Relationships in our practice can be modeled by looking at our own interrelationships with our families, to our teachings and how we engage with Mother Earth and Father Sky. By understanding how we relate to people, we can then model to families what meaningful relationships could look like. King (1990) speaks to relationships by stating:

"All my relations" is a first reminder of who we are and of our relationship with both our family and our relatives. It also reminds us of the extended relationship we share with all human beings. But the relationships that Native people see go further, the web of kinship extending to the animals, to the birds, to the fish, to the plants, to all the animate and inanimate forms that can be seen or imagined. More than that, "all my relations" is an encouragement for us to accept the responsibilities we have within this universal family by living our lives in a harmonious and moral manner (in Sinclair 2004, p.54).

In our work, we honour our relationships by inviting Elders to come speak to students. Our Elders are able to share their histories and their experiences, and impart an important and different set of learning to students.

We know and believe that children are the heart of communities and they must be central to how we look at practice. Because children are gifts from our Creator, they must be at the center of love and nurturing from a circle of extended family and community members (Cherrington, 2000, p.29). More importantly, in practice we must remember how children historically have been traumatized by colonial practices and how our children are devastated by racism. We know how policies, legislation and other laws 
have harmed our Way of Being as Indigenous peoples. For many helpers we have seen how stereotypes and assumptions have harmed Indigenous families and resulted in the removal of children from our families and communities.

Especially important in social work practice is maintaining relationships with children. Children are precious and must continue to be looked after by our families and extended families. Moreover, children must have strong relationships with people who work for them. Aboriginal children are precious to us because they represent our collective future. Anderson (2000) reminds us that children are not considered possessions of the biological parents; rather, they are understood to be gifts on loan from the Creator (p. 159). It is important to be committed to children-in-care, and moreover, be consistent in how we engage with them. As helpers, it is important to maintain relationships with the children and families we work with to the best of our abilities, most particularly those children who are in child protection. If we reflect on our traditional teachings, there were many people involved with children in our communities; these were life long relationships, which in turn, impact on the Way of Life for children. In our practice, then, we must remember that children receive many teachings, and form a variety of strong, important lifelong relationships; the relationships we forge with children will impact how they 'become' an adult. We must also remember that the children will remember what we do and say. For antioppressive living we must critically analyze how our educational teachings and training impact our relationships with children and their families. We must continuously reflect on how legislation, and organizational policies and practices could be used to strengthen families rather than create harm for children and families.

As an example, social work training and education stresses that we must learn how to be objective. We learn that there are certain standards by which to communicate and document what relationships are like between social workers and their 'clients.' We also learn how to report on the lives of children and families. For anti-oppressive practice, the question becomes, "how do we act and write in a way that is resilient and supportive for children? Can we do this ethically? How do our traditional teachings inform how we work within practice standards?"

To answer the questions posed above, we want to emphasize that to practice in a way that benefits children and who they are as human beings, we as practitioners must journey from our head to our heart. Elders and traditional teachers have taught us that the longest journey anyone makes is from the head to the heart. What does this mean for practice? And how do we do this? One reason why this head to heart journey is important is because social workers are directly involved in, and influence relationship with families - and, these relationships must be viewed as lifelong. Johnson (2000) encourages professionals to believe that personal uniqueness and differences should be valued and respected (p.133). In our mainstream western educational training we are taught to be objective: we assess, we recommend and we implement - then we move onto our next 'case file.' However, the 'heart' in our practice teaches us and encourages us to practice differently because we as people, as social workers are responsible for the relations and connections we make. We very well may see this family in another place and time, or perhaps we will share a sacred ceremony with 
this family. In our classrooms, the journey from the head to the heart is at times brought together and made present when we share ceremony with our students. Ceremony collectively connects each person, each student and ourselves with the past, present, and future, demonstrating the need to work from a holistic place - connecting the head to the heart. Ceremonies like smudging encourage students, like the teachings of the Medicine Wheel tell us, to bring forward and engage their whole person (spiritual, emotional, physical, as well as mental). When we engage in sacred ceremonies together, relationships are solidified - most times forever. For this reason, it is important that we consider all notes and communications as sacred - where any documentation must be scrupulously respected. Rather than emphasizing objectivity, we need to remember that we are communicating about our community members, our families - not our "cases."

\section{In The Northern Direction of Our Journey We Reflect On Our Practice and We Look At Vision and/or Revisioning}

For Indigenous peoples, vision is critical in our lives and for our future. We reflect on our communities, our teachings, and our ancestors to see how their lives impact who and how we are today. So, for us as practitioners, we must remember the strength and resiliency of our grandparents, our ancestors and our children who have been warriors throughout history - because we too hope to be remembered in a similar way. Despite the imposition of colonial policies, our people are alive and well. Our people are re-claiming traditional teachings and persevering our ways of life in regenerating culture, language and ceremony. Our people continue to believe in change. In practice, we understand how policies have affected the lives of so many Indigenous children. Today, we can re-do practice standards and incorporate traditional teachings into how we do our work. As we continue to re-learn our traditional ways, we know that contemporary practice must be inclusive of varying ways of being. In our relationships with non-Indigenous peoples we know that we must work collaboratively and we must model collaboration through meaningful partnerships.

Partnerships are important and meaningful. However, non-Indigenous workers, politicians and State workers must demonstrate their willingness to truly understand the historical legacies that have harmed our people and to link these to the myriad of issues that our communities are challenged by because of these legacies. As Indigenous people, there are many situations where we have been forced to engage in mainstream policies and practice standards in order to work in our own communities. It is time now for non-Indigenous workers to engage in our ways of being and practice in a way that exemplifies a way of life relevant to the people they work for. What we are invoking, here, is a call for non-Indigenous workers and politicians to shift their own cultural values and belief systems in order to collaborate in a meaningful and positive way with Indigenous peoples. This is a necessary step for re-visioning relationships.

Graveline (1998) states "resistance is essential to our survival" (p.43). Indigenous peoples have resisted assimilating and have survived. A belief in hope and vision for the future of the next seven generations is necessary to continue to challenge dominant systems.

In order to put forward the Traditional worldview, we need to continue to challenge the Western paradigms that guide today's education systems. Continued resistance needs to be mounted, as Western educational models 
are still playing a large role in reinforcing altered forms of consciousness. Thinking with the head (cognition) as separable from the heart (feelings) is expected and continuously reinforced in Western schooling (ibid., p.39).

As we reflect on this wheel of practice, we see how Indigenous peoples have resisted and are standing strong. We see how, despite the many different forms of colonial impositions, our spirits and Our Way of Being are strong. We also recognize that there are still places where our people must heal and move forward with their lives. This is true for our lives as workers as well. By collaborating in our practices, we as helpers can resist and revision to truly deconstruct colonial practices in our communities. We recognize that it is essential for us to incorporate our regenerative cultural teachings into our practice. We know that historically, culture and tradition were instrumental to healthy communities.

Acknowledging and recognizing that, although our lives, our lessons and our students are seeped in colonial mentality, we still must accept responsibility to teach, and we can rely on traditional forms to do so. I stand strong in my ability and my willingness to accept personal responsibility for understanding power and relationships and to share what I have learned through my own experiences and voice (Graveline, 1998, p.48).

In the northern direction of our work, we reflect on stories our grandmothers have shared with us. We must remember their stories so we can learn from them and live our lives accordingly of our respective traditional places. We must remember the resistance of our grandmothers and grandfathers who lived through residential school trauma and the banning of ceremonial practices. Today, we can incorporate their resistance and practice differently. We must remember that in their lives, children were and are the hearts of their communities. Today, we must ensure that children continue to be the centre of our practice. What will the children say to us if we ask them what a social worker is? How would our ancestors answer this question? As helpers, we know that our helpers were and are our grandparents, our ceremonies, and our relationship to All Living Things.

In conclusion, we want to reiterate that we have come to understand anti-oppression as A Way of Life. Reflecting on our philosophy from the Medicine Wheel, our well being (spiritual, emotional, physical and mental) are critical aspects of our lives. As we write this, we are mothers, grandmothers, students, teachers, and social workers (to name a few). We are always all these things. As such we must live the values and beliefs we embrace all the time. If we always live our values and beliefs, antioppressive social work would be based on Snuw'uy'ul - all of our traditional teachings to live a good life, to be the best human beings and helpers we can possibly be.

All Our Relations!

Kundoque - Jacquie Green

Qwul'sih'yah 'maht - Robina Thomas

\section{Endnotes}

1. The Indian Act is an enforced colonialist, paternalistic legislation that has governed and classified every aspect of the lives of Indigenous peoples in Canada for well over a hundred years. This broad, sweeping Act continues to govern, control, classify, regulate, and dictate our identity, our movements, and the economic, social, and political lives of our people today (Lawrence, 2003, p. 4).

2. A Hul'qumi'num Mustimuhw term by Hul'qumi'num speaking people. 
3. Will capitalize Our or A Way of Life to demonstrate the significance of Indigenous relationships to all living things as A Way Of Life.

\section{Bios}

Qwul'sih'yah'maht (Robina Thomas) is Lyackson of the Coast Salish Nation. Assistant Professor in the School of Social Work, Robina holds a BSW, MSW, and is working towards a $\mathrm{PhD}$ in Indigenous Governance. Robina is committed to First Nations education and her research interests include Storytelling, Residential Schools and Uy'skwuluwun: On Being Indigenous. She is committed to understanding anti-racism and anti-oppression and how these can be 'lived.

Kundoque (Jacquie Green) is from the Haisla Nation. She is an Assistant Professor in the School of Social Work. Jacquie holds a BSW, MPA, and is working towards her PhD in Indigenous Governance. Her teaching is embedded in understanding traditional knowledge and philosophies, thus looking at identity and language through storytelling. Her social work teaching includes methods to center Indigenous livelihoods and to center difference. She focuses her research, writing and teaching to Indigenous Centered knowledges to inform what social work practices could look like.

\section{References}

Aboriginal Healing Foundation (2003). Aboriginal people, resilience and the residential school legacy. Ottawa: Author. Retrieved August 8, 2006, from http://www. ahf.ca/assets/pdf/english/resilience.pdf.

Aboriginal Healing Foundation (2005). Reclaiming connections: Understanding residential school trauma among Aboriginal People. Ottawa: Author. Retrieved August 5, 2006, from http:// firstnationspedagogy.com/healing\&trauma. pdf.

Alfred, T. (2005) Wasase: Indigenous pathways of action and freedom. Broadway Press.
Alfred, T. (2004) Warrior Scholarship: Seeing the University as a Ground of Contention. In D. Mihesuah and A. Wilson (Eds.) Indigenizing the Academy: Transforming Scholarship and Empowering Communities, pp. 88-99. Lincoln: University of Nebraska Press.

Anderson, K. (2000) Recognition of Being: Reconstructing Native Womanhood. Second story Press.

Bopp, J., Bopp, M., Brown, L., \& Lane, P. (1984). The Sacred Tree: Reflections on Native American Spirituality. Twin Lakes, WI: Lotus Light Publications.

Cajete, G. (2000). Indigenous Knowledge: The Pueblo Meaphor of Indigenous Education. In Battiste, M. (Ed) Reclaiming Indigenous Voice and Vision. Vancouver, BC: UBC Press

Castellano, Marlene Brant, Davis, Lynne, and Lahache, Louise. (Eds.) (2000). Aboriginal Education: Fulfilling the Promise. Vancouver, BC: UBC Press.

Dominelli, L. (1988). Anti-Racist Social Work. London: British Association of Social Workers.

Graveline, J. (1998). Circle Works: Transforming Euro-centric consciousness. Fernwood Publishing

Green, J. and Thomas, R. (2005). Learning through our children, healing for our children: Best practice in First Nations communities. In Lena Dominelli (Ed.), Communities in a globalizing world: Theory and practice for community empowerment. Ashgate Pub.: UK

Hart, M. (2002). Seeking Mino-Pimatisiwin: An 


\section{A way of life: Indigenous perspectives on anti oppressive living}

Aboriginal Approach to Helping. Halifax: Fernwood Publishing.

Hodge, John, L. (1990). Equality: Beyond dualism and oppression. In David Theo Goldberg (Ed.), Anatomy of Racism. University of Minnesota Press: Minneapolis.

hooks, b. (1995). Killing rage: Ending racism. New York, NY: Henry Holt \& Co.

Loomba, A. (1998). Colonialism/ Postcolonialism: The New Critical Idiom. New York: Routledge.

Johnson, (2000). Envisioning a communityCentered Education: We do not own our children, we must honor them in all ways. In Maenette Kape ahiokalani Padeken Ah Nee-Benham with Cooper, J. (Eds.), Indigenous educational models for contemporary practice: In our mother's voice. Lawrence Earlbam Associates.

Lawrence, Bonita. (2003). Gender, race, and the regulation of native identity in Canada and the United States: An overview. In Hypatia. Vol 18, No. 2 (Spring). Pp. 3-31.

Lawrence, Bonita. (2002). Rewriting histories of the land: Colonization and Indigenous resistance in eastern Canada. In Sherene Razack (Ed.), Race, space, and the law: Unmapping a white settler society. Between the Lines: Toronto.

Maracle, L. (1996). I am Woman: A Native perspective on sociology and feminism. Vancouver, BC: Press Gang Publishers.

Mihesuah, D. \& A. Wilson (Eds.) (2004). Indigenizing the academy: Transforming scholarship and empowering communities. Lincoln: University of Nebraska Press.
Saulis, M (2003). Program and policy development from a holistic Aboriginal perspective. In Westhues, A. (Ed.), Canadian Social Policy: Issues and Perspective. Waterloo: Wilfred Laurier Press. Third Edition.

Simpson, Audra. (2000). Paths toward a Mohawk nation: Narratives of citizenship and nationhood in Kahnawake. In Duncan Ivison, Paul Patton and Will Sanders (Eds.), Political theory and the rights of Indigenous peoples. Cambridge University Press: Cambridge, UK.

Sinclair, R. (2004). Aboriginal social work education in Canada: Decolonizing pedagogy for the seventh generation. In First Peoples Child \& Family Review. A Journal on Innovation and Best Practices in Aboriginal Child Welfare, Administration, Research, Policy and Practice, 1(2): 49-61.

Tuhiwai Smith, L.T. (2002). Decolonizing methodologies: Research and Indigenous peoples. London: Zed Press (Fifth Edition).

Tully, James. (2000). The struggles of Indigenous peoples for and of freedom. In Duncan Ivison, Paul Patton and Will Sanders (Eds), Political theory and the rights of Indigenous peoples. Cambridge University Press: Cambridge, UK. 